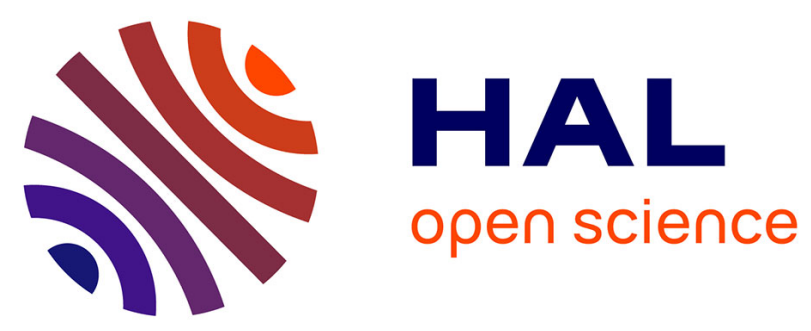

\title{
Phenolic compounds, antioxidant and antibacterial activities of three Ericaceae from Algeria
}

Naima Guendouze, Khodir Madani, Mohamed Chibane, Lila

Boulekbache-Makhlouf, Didier Hauchard, Martin Kiendrebeogo, Caroline

Stevigny, Ndjolo Okusa Philippe, Pierre Duez

\section{To cite this version:}

Naima Guendouze, Khodir Madani, Mohamed Chibane, Lila Boulekbache-Makhlouf, Didier Hauchard, et al.. Phenolic compounds, antioxidant and antibacterial activities of three Ericaceae from Algeria. Industrial Crops and Products, 2015, 70, pp.459-466. 10.1016/j.indcrop.2015.03.053 . hal-01138601

\section{HAL Id: hal-01138601 https://hal-univ-rennes1.archives-ouvertes.fr/hal-01138601}

Submitted on 15 Sep 2015

HAL is a multi-disciplinary open access archive for the deposit and dissemination of scientific research documents, whether they are published or not. The documents may come from teaching and research institutions in France or abroad, or from public or private research centers.
L'archive ouverte pluridisciplinaire HAL, est destinée au dépôt et à la diffusion de documents scientifiques de niveau recherche, publiés ou non, émanant des établissements d'enseignement et de recherche français ou étrangers, des laboratoires publics ou privés. 


\section{Phenolic compounds, antioxidant and antibacterial activities of three Ericaceae from} Algeria

Naïma Guendouze ${ }^{\mathrm{a}}$, Khodir Madani ${ }^{\mathrm{a}}$, Mohamed Chibane ${ }^{\mathrm{b}}$, Lila Boulekbache-Makhlouf ${ }^{\mathrm{a}}$,

Didier Hauchard $^{\mathrm{c}}$, Martin Kiendrebeogo ${ }^{\mathrm{d}}$, Caroline Stévigny ${ }^{\mathrm{e}}$, Philippe Ndjolo Okusa ${ }^{\mathrm{f}}$, Pierre

$$
\text { Duez }^{\mathrm{e}, \mathrm{f}}
$$

${ }^{a}$ Laboratoire de Biomathématique, Biochimie, Biophysique et Scientométrie, Faculté des Sciences de la Nature et de la Vie, Université de Bejaia 06000, Bejaia, Algérie

${ }^{\mathrm{b}}$ Faculté des Sciences de la Nature et de la Vie et Sciences de la Terre, Centre Universitaire de Bouira 10000, Algérie

${ }^{c}$ Laboratoire des Sciences Chimiques de Rennes, UMR CNRS 6226, Ecole Nationale Supérieure de Chimie de Rennes, France

${ }^{\mathrm{d}}$ Laboratoire de Biochimie et Chimie Appliquées (LABIOCA), Université de Ouagadougou, Burkina Faso

${ }^{\mathrm{e}}$ Laboratoire de Pharmacognosie, Bromatologie et Nutrition Humaine, Faculté de Pharmacie, Université Libre de Bruxelles (ULB), Belgium

${ }^{\mathrm{f}}$ Laboratoire de Chimie Thérapeutique et de Pharmacognosie, Faculté de Médecine et de Pharmacie, Université de Mons (UMONS), Belgium

Corresponding authors:lilaboulekbachemakhlouf@yahoo.fr

Tel: +213552932738; Fax: +21334214762 


\section{ABSTRACT}

Herbs of the Ericaceae family are commonly found in Algeria and used in traditional medicine as antiseptic, diuretic, astringent, depurative, and to treat scalds and wounds. The methanolic extracts of three species, Arbutus unedo L. (A. unedo, leaves), Erica arborea L. (E. arborea, flowered aerial parts), and Erica multiflora L. (E. multiflora, flowered aerial parts), were compared regarding their content in phenolic compounds, their antioxidant, and antibacterial activities. A. unedo harbors the highest content in total phenolics and flavonoids, followed by E.arborea and E.multiflora. The contents in total phenolics and flavonoids showed a correlation with the measured antioxidant (hydrogen-donating) activities; this was particularly the case for flavonoids content. The A. unedo extract showed antibacterial activity against all the tested strains (Staphylococcus aureus ATCC 6538, Staphylococcus aureus C100459, Escherichia coli ATCC 25922, and Pseudomonas aeruginosa ATCC 9027); however, the E. arborea and E. multiflora extracts showed antibacterial activity only against Gram positive bacteria. Some polyphenols were identified in the three herbs by thin-layer chromatography and high-performance liquid chromatography coupled with diode array and mass spectrometry detection; from these, caffeic acid, $p$-coumaric acid, naringin, quercetin and kaempferol are reported for the first time in E. multiflora.

Keywords: Ericaceae, polyphenols, antioxidant activity, HPLC-DAD-ESI-MS analysis, antibacterial activity. 


\section{Introduction}

In many countries, including Algeria, folk medicines widely resort to medicinal plants as primary tools to treat many diseases; the study of such traditional practices has uncovered many drugs of importance and is still a cornerstone of modern drug discovery (Newman and Cragg, 2012). In the last decades, herbal medicines have received much attention in Western and Eastern countries as sources of biologically active substances, notably for the discovery of antioxidant, antimutagenic, anticarcinogenic and cytotoxic agents (Parejo et al., 2003).

The Ericaceae, a large cosmopolitan family represented by 4100 species regrouped in 124 genera, notably Arbutus, Calluna and Erica, present the highest diversity under the Mediterranean climates (Lhuillier, 2007). Medicinal properties have long been recognized for some Ericaceae which led to their inclusion in the list of species that may enter into the composition of herbal medicines (Bruneton, 2001). The therapeutic functions of Ericaceae species are generally attributed to their abundant (poly) phenolic compounds (MarquezGarcia et al., 2009).

From this family, E. arborea, E. multiflora and A. unedo are commonly found in Algeria and used for various medicinal properties; the Erica species are notably used to treat wounds and scalds. Also named "tree heath", E. arborea is a shrub that usually measures up to $4 \mathrm{~m}$ high and even more in the old bush (Meyer et al., 2004). This species is distributed in the Mediterranean region, in the west of Portugal, in the Canary Islands (La Mantia et al., 2007) and in Northern Africa; it is found in Morocco, Tunisia and Algeria, where it is common in altitude scrubland, in Aures mountains and Ksour Range (Ait Youssef, 2006). E. arborea is considered as an astringent plant (Bezanger-Beauquesne et al., 1990); its aerial parts have many traditional uses as antiulcer, antimicrobial, cytotoxic, anti-edema (Akkol et al., 2007; Marquez-Garcia et al., 2009), antidiarrheal and healing agent (Ait Youssef, 2006). 
According to Ay et al. (2007), its leaves and flowers are used in many countries as diuretic, urinary antiseptic, and against constipation. Flavonoids and phenolics are the main compounds isolated from this species that also contains terpenoids, coumarins and essential oils (Ait Youssef, 2006; Garnier et al., 1961).

E. multiflora, known as "many-flowered heather", a sub-shrub with evergreen needlelike foliage (Vilà and Terradas, 1998), is present in Northern Africa and France. In Algeria, the species is common all along the coast; it grows mainly in scrublands and is very rare in Kabylia (Ait Youssef, 2006). The flowering tops of E. multiflora are used to treat hyperlipidemia (Harnafi et al., 2007), atherosclerosis, prostate cancer (Ait Youssef, 2006), and as antiseptic, diuretic (Harnafi et al., 2007), anti-inflammatory (Sadki et al., 2010), astringent, sedative, and wound-healing agent (Rios et al., 1987).Tannins, proanthocyanidols and flavonoids represent major compounds of the flowers (Bruneton, 1987). The E. multiflora leaves ethyl acetate extract and its active compound lupenone (lup-20(29)-en-3-one) stimulate melanogenesis by increasing the tyrosinase enzyme expression at both the transcriptional and translational levels, making it a possible treatment for hypopigmentation diseases (Villareal et al., 2013).

A. unedo, known as "strawberry tree", is an evergreen shrub widely distributed in the Mediterranean basin (Ait Youssef, 2006; Fortalezas et al., 2010; Navarro et al., 2007) and South-Western Asia (Ait Youssef, 2006).The fruits are used in the production of alcoholic beverages, jams, jellies and marmalades (Ayaz et al., 2000; Serce et al., 2010; Takrouni and Boussaid, 2010); they are also used in folk medicine for the treatment of gastrointestinal, dermatological, urological, cardiovascular and gastritis disorders, and for their antimicrobial activity (Ruiz-Rodríguez et al., 2011). This organ is also a good source of antioxidants (Pallauf et al., 2008), including phenolic compounds (e.g. flavonoids, anthocyanins, gallic acid derivatives and tannins), vitamin C, vitamin E, and carotenoids (Fortalezas et al., 2010). 
A. unedo leaves are used for astringent, antiseptic, urinary antiseptic, diuretic, antidiarrheal, depurative, anti-inflammatory and antioxidant properties, and in the therapy of hypertension, diabetes and gonorrhea (El Haouari et al., 2007; Kivçac and Mert, 2001; Oliveira et al., 2009). As mentioned by Ait Youssef (2006), A. unedo leaves are used for direct application on recurrent skin diseases, like eczema or fungal infections. The antiaggregant activity of leaves extracts has been proposed for the treatment and/or prevention of cardiovascular diseases (Andrade et al., 2009; Mariotto et al., 2008). The antihypertensive effect has been attributed to their richness in phenolic compounds, including tannins (Afkir et al., 2008; Pallauf et al., 2008). The roots are disinfectant of the urinary tract (Garnier et al., 1961), anti-inflammatory, laxative, carminative, digestive, odontalgic, and cardiotonic (Barros et al., 2010). Potentially bioactive compounds, including lipids, tannins, vitamin E (Pabuccuoglu et al., 2003), triterpenoids, flavonoids (Fiorentino et al., 2007), aromatic acids, iridoids, monoterpenoids, phenylpropanoids, and sterols, have been described in the leaves of A. unedo (RuizRodríguez et al., 2011).

Based on their reported traditional uses and phenolic compositions, particularly flavonoids, proanthocyanidins and phenolic acids, Ericaceae may be a potential source for clinically relevant antioxidant and/or antibacterial agents. Given the widespread distribution and utilization of E. arborea, E. multiflora and A. unedo in Algeria, the present work aims at validating these folk uses by investigating polar extracts of local cultivars for total phenolics, flavonoids content, antioxidant, and antibacterial activities. Major compounds will be profiled through thin-layer chromatography (TLC) and high-performance liquid chromatography coupled with diode array and mass detection (HPLC-DAD-ESI-MS).

\section{Material and methods}

\subsection{Chemicals and culture medium}


Folin Ciocalteu's, 2,2-diphenyl-1-pycryl hydrazyl (DPPH), apigenin, arbutin, epicatchin,salicylic acid, ethyl gallate, chlorogenic acid and sodium monocarbonate were obtained from Sigma-Aldrich (St.Louis, USA), catechin, 2,2-azinobis-3-ethylbenzothiazoline6-sulfonic acid (ABTS), tetrabutylammonium hexafluorophosphate $\left(\mathrm{Bu}_{4} \mathrm{NPF}_{6}\right)$, dimethylformamide (DMF) and hesperidin were from Fluka (Sigma Aldrich, St.Louis, USA), dimethylsulfoxyde (DMSO) and resorcinol from Merck (Darmstadt, Germany), quercetin from Riedel-de Haen (Seelze, Germany), aluminium chloride and methanol from Biochem Chemopharma (Quebec, Canada),kaempferol, galangin and 4-OH benzoic acid from Carl Roth (Karlsruhe, Belgium), rutin from Alfa Aesar (Ward Hill, USA), delphinidin from Extrasynthèse (Genay, France), caffeic acid from Janssen Chemica (Geel, Belgium),gallic acid, $m$-coumaric acid and $p$-coumaric acid from Koch Light Laboratories (Gauteng South Africa, South Africa), and potassium persulfate from Rhone-Povalenc (Paris, France). The Mueller Hinton broth was from Oxoid (Hampshire, UK). Cefotaxim $(30 \mu \mathrm{g})$ and streptomycin were used as control for the microdilution assay (Taastrup, Denmark). Staphylococcus aureus ATCC 6538, Escherichia coli ATCC 25922 and Pseudomonas aeruginosa ATCC 9027 were obtained from the American Type Culture Collection (ATCC, Manassas, USA).The Staphylococcus aureus C100459 was a methicillin-resistant (MRSA) clinical isolate from the Centre Hospitalier Universitaire of Charleroi (Belgium).

\subsection{Plant material}

The leaves of A. unedo (November 2008; voucher specimen BR 0000005333 905), the flowered aerial parts of E. arborea (April 2009; voucher specimen BR 0000005334 223), and E. multiflora (November 2008; voucher specimen BR 0000005334 551) were collected in the Region of Ait Guendouze in the Boukhlifa township (Bejaia, Algeria). They have been 
dried at room temperature (in the shade), then ground and sieved in order to obtain a fine powder $(<125 \mu \mathrm{m})$. The three species were identified by a local botanist, and confirmed by Prof. J. Lejoly (Université Libre de Bruxelles, Belgium). Voucher specimens were deposited in the herbarium of the National Botanic Garden of Belgium (Meise, Belgium).

\subsection{Extract preparation}

The samples $(5 \mathrm{~g})$ were defatted with $15 \mathrm{~mL}$ of $\mathrm{n}$-hexane, dried, and extracted by stirring at $130 \mathrm{rpm}$ with $100 \mathrm{~mL}$ of methanol, at room temperature for $24 \mathrm{~h}$, then filtered on cellulose (Soares et al., 2009). The filtrates were dried, reconstituted with methanol and stored at $4{ }^{\circ} \mathrm{C}$ until use.

\subsection{Determination of total phenolics}

The content of total phenolics was determined by the Folin-Ciocalteu method (Singleton and Rossi, 1965). To $0.1 \mathrm{~mL}$ of the extract ( $1 \mathrm{~g} / \mathrm{L}$ ) or of gallic acid solution ( 2 to $9 \mathrm{mg} / \mathrm{L}$ ), $2 \mathrm{~mL}$ of water and $0.5 \mathrm{~mL}$ of the Folin-Ciocalteu reagent were added. After $1 \mathrm{~min}, 1.5 \mathrm{~mL}$ of a saturated solution of sodium carbonate was added and the total volume adjusted to $10.0 \mathrm{~mL}$ with water. The solutions were mixed, allowed to stand (in the dark) for $2 \mathrm{~h}$ at room temperature. Then, the absorbance was measured at $760 \mathrm{~nm}$ versus a blank prepared without extract. The total phenolic content was expressed as milligram gallic acid equivalents per gram of dry weight (GAE/g of DW) (Bramorski et al., 2011).

\subsection{Determination of flavonoids}

The content in total flavonoids was determined by the $\mathrm{AlCl}_{3}$ method of Lamaison and Carnet (1990). $1.0 \mathrm{~mL}$ of the extract ( $1 \mathrm{~g} / \mathrm{L}$, diluted by $1 / 2$ for E.arborea and by $1 / 3$ for A.unedo) or of quercetin (1.25 to $20 \mathrm{mg} / \mathrm{L})$ was mixed with $1 \mathrm{~mL}$ of methanolic $\mathrm{AlCl}_{3}(0.1 \mathrm{M})$, incubated in 
the dark for $10 \mathrm{~min}$ and measured at $455 \mathrm{~nm}$ versus a blank prepared without extract. The total flavonoids content was expressed as milligram quercetin equivalents per gram of dry weight $(\mathrm{QE} / \mathrm{g}$ of $\mathrm{DW})$.

\subsection{Determination of the antioxidant activity}

The antioxidant activity was measured by three in vitro methods, using free radicals DPPH*, $\mathrm{ABTS}^{\circ+}$ and electro-generated $\mathrm{O}_{2}{ }^{--}$(anion superoxide radical).

\subsubsection{Measurement of $\mathrm{DPPH} H^{\bullet}$ quenching}

The hydrogen donating and/or radical-scavenging capacity of the samples was evaluated by their ability to scavenge the free radical $\mathrm{DPPH}^{\bullet}$ according to Blanc et al. (2011). For each extract, five dilutions in methanol were prepared (1.93 to $9.67 \mathrm{mg} / \mathrm{L}) .2 \mathrm{~mL}$ of each dilution were added to $0.15 \mathrm{~mL}$ of a $10^{-3} \mathrm{M} \mathrm{DPPH}^{\bullet}$ methanolic solution and maintained in the dark at room temperature for $1 \mathrm{~h}$. The absorbance was measured at $517 \mathrm{~nm}$ versus a blank prepared without extract (Blois, 2002).

\subsubsection{Measurement of $\mathrm{ABTS}^{\circ+}$ quenching}

The $\mathrm{ABTS}^{\circ+}$ stock solution was prepared by dissolving $7 \mathrm{mM}$ ABTS and $2.45 \mathrm{mM}$ potassium persulfate and incubating for $12-16 \mathrm{~h}$ at room temperature in the dark. The working solution was obtained by diluting with ethanol to an absorbance of $0.70 \pm 0.02$ at $734 \mathrm{~nm} .10 \mu \mathrm{L}$ of the extract ( 2 to $10 \mathrm{~g} / \mathrm{L}$ ) were added to $0.99 \mathrm{~mL}$ of diluted $\mathrm{ABTS}^{\circ+}$, incubated in the dark at room temperature for $30 \mathrm{~min}$ and the absorbance was measured at $734 \mathrm{~nm}$ versus a blank prepared without extract (Re et al., 1999).

\subsubsection{Measurement of $\mathrm{O}_{2}{ }^{-*}$ quenching}




\section{Electrochemical material}

Cyclic voltammetry experiments were performed on a dual potentio-galvanostat PGSTAT30 (Autolab instrument, Eco Chemie B.V., Utrecht, The Netherlands) driven by a GPES software (General Purpose Electrochemical System version 4.9, Eco Chemie B.V.). All measurements were carried out on a three- electrode thermostated cell. A glassy carbon disk working electrode (diameter $2 \mathrm{~mm}$ ), a platinum wire counter electrode and a reference electrode, $\mathrm{Ag} / \mathrm{AgCl}$ in $\mathrm{EtOH}$ saturated by $\mathrm{LiCl}$, were used for all electrochemical experiments. The reference electrode was separated from the solution by a salt bridge containing $0.5 \mathrm{MBu}_{4} \mathrm{NPF}_{6}$ in DMF. The glassy carbon disk working electrode was polished using silicon carbide 4000 paper with a LaboPol-5 (Struers, Ballerup, Denmark), washed with distilled water and then dried. For all measurements, the temperature was maintained at $21 \pm 0.5{ }^{\circ} \mathrm{C}$ with a Julabo heating circulator MP-5 (Julabo, Seelbach, Germany).

\section{Quenching of $\mathrm{O}_{2}{ }^{--}$}

The methodology developed by Le Bourvellec et al. (2008) is based on the reaction kinetics of the antioxidant substrate with the superoxide anion radical $\left(\mathrm{O}_{2}{ }^{-}\right)$. A cyclic voltammetry forward scan generates $\mathrm{O}_{2}{ }^{--}$by reduction of molecular oxygen in an aprotic medium, N, Ndimethylformamide (DMF); the consumption of the radical $\mathrm{O}_{2}{ }^{--}$is directly measured at the backward scan by the anodic current decay from its oxidation in the presence of Ericaceae extracts.

A solution of $10 \mathrm{~mL}$ of an extra dry DMF $\left(\left[\mathrm{H}_{2} \mathrm{O}\right] \leq 0.01 \%\right)$, stored over molecular sieve

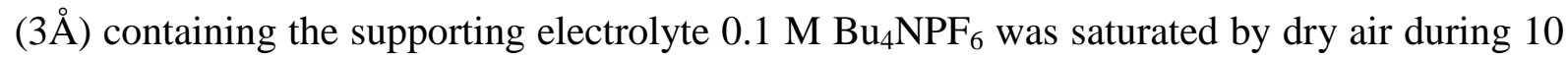
min. In these conditions, the solubility of oxygen was assumed to be $C_{O_{2}} \approx 9.4 \times 10^{-4} \mathrm{~mol} / \mathrm{L}$, this value corresponding to a partial pressure of 0.2 bar at $293 \mathrm{k}$ (Dapremont-Avignon et al., 1991). The cyclic voltammogramm (CV) of the oxygen reduction was then recorded at a scan 
rate $0.1 \mathrm{~V} / \mathrm{s}$, with the initial potential at $0 \mathrm{~V}$ and the reverse one at $-1.3 \mathrm{~V}$ vs. $\mathrm{Ag} / \mathrm{AgCl}$. Stock solutions of the standard antioxidant or herbal extracts were prepared at about $4 \mathrm{~g} / \mathrm{L}$ for A.unedo and E.arborea extracts and $6 \mathrm{~g} / \mathrm{L}$ for E.multiflora extract. For each extract, aliquots of stock solution were successively added to $10 \mathrm{~mL}$ of oxygen solution in order to get an extract concentration in the range of $30-450 \mathrm{mg} / \mathrm{L}$. After each aliquot addition, the $\mathrm{CV}$ plot of the oxygen solution was recorded at a scan rate $0.1 \mathrm{~V} / \mathrm{s}$. The measurement of the antioxidant activity is estimated by the antioxidant index values $A I 30$ or $A I_{50}$, defined as the phenolic compound or extract concentration needed to consume, respectively $30 \%$ or $50 \%$ of the electrogenerated radical [corresponding to $\left(\mathrm{Ip}_{\mathrm{a}}{ }^{0}-\mathrm{Ip}_{\mathrm{a}}{ }^{\mathrm{S}}\right) / \mathrm{Ip}_{\mathrm{a}}{ }^{0}=0.3$ or 0.5 where $\mathrm{Ip}_{\mathrm{a}}{ }^{0}$ is the intensity of the anodic current peak of $\mathrm{O}_{2}{ }^{--}$and $\mathrm{Ip}_{\mathrm{a}}{ }^{\mathrm{S}}$ the intensity of the anodic current peak of $\mathrm{O}_{2}{ }^{-}$for the concentration $\mathrm{S}$ of the sample]. With this characterization, the lower the $\mathrm{AI}_{30}$ or $\mathrm{AI}_{50}$ value, the more the substrate has a strong reactivity toward the superoxide.

\subsection{Antibacterial assay}

Each plant extract was dissolved in DMSO $(80 \mathrm{~g} / \mathrm{L})$, then diluted to $5.0 \mathrm{~mL}$ with Mueller Hinton broth; on 96-well micro-plates, this solution was $1 / 2$ serially diluted with the same broth, added with $0.1 \mathrm{~mL} /$ well of bacterial inoculum $\left(10^{6}\right.$ bacteria $\left./ \mathrm{mL}\right)$ and incubated at $37^{\circ} \mathrm{C}$ for $24 \mathrm{~h}$ in ambient atmosphere. The MIC (the minimum inhibitory concentration) was defined as the lowest antimicrobial concentration that completely inhibited growth as detected by the naked eye (Brantner and Grein, 1994; Chérigo et al., 2009). The MBC (the minimal bactericidal concentration) was defined as the lowest concentration that yielded negative subcultures (Mandal et al., 2010; Okusa et al., 2007).

\subsection{Synergy between plant extracts and antibiotics}


The eventual synergy between plant extracts and antibiotics was evaluated on Staphylococcus aureus C100459 and Pseudomonas aeruginosa ATCC 9027 by a broth microdilution method according to Okusa et al. (2007). Compounds were placed into 96-wells culture plates to obtain mixtures covering a broad range of suboptimal concentrations of both compounds. The values of Fractional Inhibitory Concentrations (FIC) and FIC index were determined to evaluate if the interaction extract/antibiotic is synergistic, antagonistic or indifferent. The FIC index was calculated according to the equation: FIC index = FICA + $\mathrm{FICB}=(\mathrm{MIC}$ of drug $\mathrm{A}$ in combination/MIC of drug $\mathrm{A}$ alone $)+(\mathrm{MIC}$ of drug $\mathrm{B}$ in combination/MIC of drug B alone). The FIC index was evaluated as follows: synergy (FIC index $\leq 0.5)$, additive $(0.5<$ FIC index $\leq 1)$, indifference $(1<$ FIC index $\leq 2)$ and antagonism (FIC index > 2) (Jarrar et al., 2010; Mackay et al., 2000; Okusa et al., 2007).

\subsection{TLC analysis}

For both analyzes, TLC and HPLC, the extracts were analyzed before and after acid hydrolysis (with $\mathrm{HCl} 1.2 \mathrm{M}, 100^{\circ} \mathrm{C}, 1 \mathrm{~h}$ ).

For TLC, the analysis was performed on Silicagel 60 F254 plates (Merck, Germany). The solvent system used was ethyl acetate, formic acid and water (90:6:6, v/v/v); plates were sprayed with a solution of aminoethanol diphenylborate $(1 \% \mathrm{MeOH})$ then a solution of macrogol 400 (5\% MeOH) and visualized under UV $366 \mathrm{~nm}$ (Wagner and Bladt, 1996).

\subsection{HPLC-DAD-ESI-MS profiling of polyphenolic compounds}

Major phenolic compounds were identified by comparing retention times, UV spectra and mass spectra of samples peaks with those of standards. LC-DAD analysis was carried out using a quaternary pump (TSP P4000), a diode array detector (TSP UV 6000), an online vacuum degasser, a column oven and an autosampler (TSP). The LC-DAD system was 
connected to a Finnigan LCQ DUO mass spectrometer via an electrospray ionization (ESI) interface using a post-column passive splitter. Chromatographic separations were achieved at a constant flow rate of $1.2 \mathrm{~mL} / \mathrm{min}$ on an Altima C18 column $(250$ x $4.6 \mathrm{~mm}$ i.d.; $5 \mu \mathrm{m}$; Alltech, Deerfield, USA) maintained at $40^{\circ} \mathrm{C}$. A linear gradient elution was performed with mobile phase A (19\% acetonitrile, $80 \%$ water, $1 \%$ formic acid) and mobile phase B (59\% acetonitrile, $40 \%$ methanol, $1 \%$ formic acid) as follows: $0 \mathrm{~min}, 0 \% \mathrm{~B} ; 5 \mathrm{~min}, 0 \% \mathrm{~B} ; 15 \mathrm{~min}$, 15\% B; 20 min,15\% B; 40 min, 60\% B; 45 min, 100\% B. By solvent splitting, 1 mL/min flow rate was delivered into the $\mathrm{DAD}$ detector and $0.2 \mathrm{~mL} / \mathrm{min}$ into the mass spectrometer ionization source. DAD detection wavelengths were set at 280, 320 and $350 \mathrm{~nm}$ with peak scanning between 190 and $800 \mathrm{~nm}$. Full scan mass spectra were registered in negative mode between 50 and $800 \mathrm{~m} / \mathrm{z}$. Chromatographic and mass spectrometry data were acquired and processed using the instrument built-in LCQ software.

\subsection{Statistical analysis}

All determinations were carried out in triplicate. Data were compared by a variance analysis (ANOVA) carried out with the software Statistica 5.5 and $P$ values less than 0.05 were considered significant.

\section{Results and discussion}

\subsection{Total phenolics content}

Table 1 presents the total phenolics and flavonoids along with the antioxidant capacity of the three Ericaceae extracts. The A.unedo extract presents the highest concentration of total phenolic compounds, amounting to $179.6 \pm 6.7 \mathrm{mg}$ GAE/g; this is however lower than previously reported in Portuguese samples (193mg GAE/g, 329 mg GAE/g in ethanolic and acetonic extracts, respectively) (Andrade et al., 2009; Oliveira et al., 2009). Data from Erica 
species are difficult to compare as published studies express the total phenolics either in pyrogallol equivalents (PE) for E. arborea from Turkey (145 mg PE/g) (Ay et al., 2007), or in catechin equivalents (CE) for the same plant from Spain (249 mg CE/g) (Ammar et al., 2005); and for E. multiflora flowers from Morocco (105 mg CE/g) (Harnafi et al., 2007). In another study on the ethanol extract of the leaves of E. arborea (harvested in Morocco), the content of total polyphenols is about $78.49 \pm 0.05 \mathrm{mg} \mathrm{GAE} / \mathrm{g}$ DM (Amezouar et al., 2013).

\subsection{Total flavonoids content}

From Table 1, A. unedo leaves also contain the highest amount of flavonoids; samples from Croatia have previously been found to range from 5 to $20 \mathrm{mg} \mathrm{QE} / \mathrm{g}$ (Males et al., 2006). From published data, the flavonoids content of E.arborea seems quite variable. In Turkish samples, Ay et al. (2007) reported $35 \mathrm{mg} Q E / g$ (methanolic extract); in Moroccan samples, Harnafi et al. (2007) reported $0.13 \mathrm{mg} \mathrm{QE} / \mathrm{g}$ (methanolic extract) and Amezouar et al. (2013), $54 \mathrm{mg}$ QE/g (ethanolic extract). The reasons for such differences are not clear. But, as stated by Xia et al. (2014), the geographical and climatic conditions can lead to significant differences in both the concentrations of bioactive compounds in plants and their bioactivity for human health; they reported significant differences in total flavonoids in fern samples obtained from different regions.

\subsection{Antioxidant activity}

For DPPH and ABTS tests, the results were expressed in terms of $\mathrm{IC}_{50}$ value, the concentration of extract required to quench $50 \%$ of test radical (Andrade et al., 2009; Bougatef et al., 2009). As expected, an excellent correlation was observed between the DPPH and ABTS results $(r=0.96)$; this is due to the similarity of the two methods that measure the 
ability of antioxidants to donate an $\mathrm{H}$ atom (Huang et al., 2005). There were significant differences between the herbs for both assays.

The $\mathrm{O}_{2}{ }^{-}$quenching activity is estimated through an electrochemical method that determines the antioxidant index values $A I_{30}$ or $A I_{50}$ (see 2.6 .3 in the experimental section).This recently developed electrochemical method has been applied successfully to seaweed extracts (Audibert et al., 2010; Blancet al., 2011). Here, the method to determine the peak currents is different than in these previous works as the cyclic voltammograms were exploited by using convolution time semi-derivative transformation for the peak current measurements (Oldham and Spanier, 1973). The resulted convolution curves are much better resolved compared to the asymmetric voltammetric curves. As the baselines are simpler to define, the oxidation current before and after polyphenolic extract additions can be more easily measured (Fig. 1).

The values of $\mathrm{AI}_{30}$ and $\mathrm{AI}_{50}$ for each Ericaceae extract are consigned in Table 1. Although the number of species is low, a weak logarithmic relationship was observed between the measured antioxidant $\left(\mathrm{DPPH}^{\circ}, \mathrm{ABTS}^{\circ+}\right.$ and $\mathrm{O}_{2}{ }^{-}$scavenging) activities and the contents in total phenolics $\left(\mathrm{R}^{2}=0.57,0.82,0.64\right.$, respectively; $\left.\mathrm{n}=3\right)$ and flavonoids $\left(\mathrm{R}^{2}=0.82,0.98,0.88\right.$, respectively; $\mathrm{n}=3$ ); the correlation was somewhat better for flavonoids, indicating that the quality of polyphenols/flavonoids in a herb is certainly more important than their content. This is in line with correlation data "DPPH scavenging vs total flavonoids" previously obtained on Chinese fern samples (Xia et al., 2014). Vasco et al. (2008) indicate that the correlation effectively depends on the extraction solvent, the hydrophilicity of the compounds, the sample, and the type of phenolic compound. By evidence, not all antioxidant characteristics are assessed by the tests performed here; notably, the ability to quench in vivo oxidative damage and lipid peroxidation largely depends on the lipophilicity of the compounds (phenols, tocopherols, carotenoids, flavonoid aglycones) and the chelation of 
metals (ascorbic acid, tannins, flavonoid aglycones and glycosides) (Bramorski et al., 2011). As for polyphenols and flavonoids content, the scarce data from the literature appear quite difficult to compare. For Moroccan E.arborea, Amezouar et al. (2013), with a much higher total flavonoids content, measured a lower DPPH radical scavenging potential $\left(\mathrm{IC}_{50}=10 \mathrm{mg} / \mathrm{L}\right.$ for a total flavonoids content of $54 \mathrm{mg} \mathrm{QE} / \mathrm{g})$, compared to the present study $(5.7 \mathrm{mg} / \mathrm{L}$ for a total flavonoids content of $9.5 \mathrm{mg} \mathrm{QE} / \mathrm{g}$ ); for Portuguese A.unedo, Mendes et al. (2011) report a much lower DPPH radical scavenging potential $\left(\mathrm{IC}_{50}=87 \mathrm{mg} / \mathrm{L}\right)$, compared to the present study (3.8 mg/L). Such apparently discording data should be more closely investigated and, indeed the qualitative and quantitative differences in polyphenol profiles should be correlated with their antioxidant power. The structure of polyphenols is certainly the most important parameter, with structural features strongly conditioning the redox power (Öztürk et al., 2007; Williams et al., 2004); the presence of 2, 3 unsaturation in conjugation with a 4-oxo- function in the C-ring and the presence of functional groups capable of binding transition metal ions indicate the possibilities of oxidation to quinoid forms and consequent high reduction power. Given the complexity of polyphenols and flavonoids profiles in the three species, only the coupling of antioxidant and metabolomics studies of samples harvested in different locations will be able to sort out the qualitative and quantitative features most important for biological activity (Hernández et al., 2009). Although studies are being carried out, for example on Acacia species (Abdel-Farid et al., 2014) or on tomato (Bovy et al., 2007), a practical method for correlating profiles with antioxidant capacity is not yet available.

\subsection{Antibacterial activity}

Tables 2 and 3 detail the antibacterial effects of the three tested herbs. According to Okusa et al. (2007), extracts displaying a MIC below $500 \mathrm{mg} / \mathrm{L}$ are considered worthy of further investigation; from 500 to $1000 \mathrm{mg} / \mathrm{L}$, the antimicrobial activity is judged weak and, 
over $1000 \mathrm{mg} / \mathrm{L}$, the extract is considered inactive. All these extracts have an interesting activity against Gram positive bacteria but not against Gram negative bacteria which are well known for their higher resistance, related to lipopolysaccharides in their outer membrane (Murray et al., 2009). Table 3 shows that the effects observed on Gram-positive bacteria are rather bactericidal (MBCs within a two-fold dilution of the MICs) than bacteriostatic (MBCs values at least within an eight-fold dilution of the MICs). E. multiflora has already been reported for weak antibacterial effect against Staphylococcus aureus with a MIC of 1000 $\mathrm{mg} / \mathrm{L}$ (Rios et al., 1987) and this activity was attributed to phenolic compounds (flavonoids and phenolic acids) and sesquiterpene lactones; the latter phytochemicals class is infrequent in Ericaceae that are rather known for their richness in polyphenols. Polyphenols and tannins possess a strong binding ability to different molecular structures like proteins or glycoproteins (Wagner and Ulrich-Merzenich, 2009). They may bind to bacterial adhesins and, by doing so; disturb the exposition of receptors on the cell surface.

Havsteen (2002) has noted that many of the bacterial strains commonly encountered by humans are killed by flavonoids. The bactericidal effect of the flavonoids may well be the result of a metabolic perturbation. Ion channels, which are components of both bacterial and animal cells, are especially sensitive points of inhibition and likely targets of flavonoids.

Arbutoside, a hydroquinone glycoside, has been reported in E.arborea (Ay et al., 2007) and A.unedo (Fiorentino et al., 2007); its hydrolysis by bacteria and spontaneous oxidation to benzoquinone may account for observed antimicrobial effects. Follow-up purification studies are however required to determine which compounds exactly may be responsible for the observed antibacterial activities.

\subsection{Interaction between plant extracts and antibiotics}


Staphylococcus aureus C100459 and Pseudomonas aeruginosa ATCC 9027 were used to test the effect of combination of plant extracts with two antibiotics (cefotaxim and streptomycin). Table 4 indicates that E. arborea and E. multiflora extracts were additive with cefotaxim and streptomycin (FIC index $=1$ ) against Staphylococcus aureus only. The A. unedo extract showed indifference effects against all the tested microorganisms/antibiotics combinations. Hatano et al. (2005) report the antibacterial effects of various plant phenolics, including flavonoids and tannins, some flavonoids and xanthones being effective against MRSA. These phenolics act either directly or by restoring the antibacterial effects of antibiotics.

\subsection{TLC and HPLC-DAD-ESI-MS analysis}

The polyphenolic composition of the polar extracts from the three Ericaceae species was investigated using TLC (Fig. 2) and HPLC-DAD-ESI-MS (Table 5). The major polyphenols of E.multiflora (Fig. 3) are reported here for the first time.

Marquez-Garcia et al. (2009) reported the following phenolic compounds in E.arborea exposed to different degrees of metal pollution in soils: ellagic acid, vanillic acid, cinnamic acid derivate, $m$-coumaric acid, caffeic acid and its derivate, $2 p$-coumaric acid derivate, catechin and 8 of its derivates, epicatechin, rutin and 4 of its derivates, kaempferol and myricetin. In this species were also reported epicatechin, quercetin, arbutoside, tannins (Ay et al., 2007), proanthocyanidols, and coumarins (Ait Youssef, 2006).

Regarding E.multiflora, Akkol (2007) and Harnafi et al. (2007), have simply noted that this species contains flavonoids, tannins, proanthocyanidins and coumarins. Ozcan and Haciseferogullari (2007) and Pallauf et al. (2008) have noted that A.unedo, contains gallic, ellagic and $p$-hydroxybenzoic acids. According to Males et al. (2006), it also contains vanillic, syringic and chlorogenic acids. This plant is also reported to contain some flavonoids, 
including arbutoflavonol $\mathrm{A}$ and $\mathrm{B}$, afzelin, juglanin, avicularin, quercetin, isoquercetin, hyperoside and anthocyanosides (Fiorentino et al., 2007; Males et al., 2006), tannins, notably proanthocyanidins, ethyl gallate and catechin (Ayazet al., 2000; Fiorentino et al., 2007; Males et al., 2006). Arbutoside, a phenolic glycoside, is also described in A.unedo (Fiorentino et al., 2007; Garnier et al., 1961; Valnet, 1992).

\section{Conclusion}

Although the polar extract of A.unedo leaves presents sensibly higher polyphenols and flavonoids levels and lower $\mathrm{IC}_{50}$ than the two Erica species investigated, all the three species present relatively potent antibacterial and antioxidant activities that could explain their use for the treatment of scalds and wounds in traditional Algerian medicine. The profiling of phenolic acids and flavonoids by TLC and HPLC-DAD-MS has allowed identifying some of the major polyphenols but should be pursued to obtain a better comprehension of polyphenolic compounds distribution in Ericaceae.

\section{Acknowledgements}

The authors acknowledge Léocadie Kamagaju and Francine Nsuadi Manga for their advices; the technical help of Mrs. Manuela De Lorenzi, Mrs. Marie Faes and Mr. Olivier Vaillant is gratefully acknowledged. A big thanks for Mrs. Aicha Tazamoucht and Mrs. Rabah Guendouze and Mr.Youcef Guendouze for their help in the collection and sample preparation. My sincere thanks to Mr. Salim Ouchemoukh for his help in the statistical analysis.

\section{References}

Abdel-Farid, I.B., Sheded, M.G., Mohameda, E.A., 2014. Metabolomic profiling and antioxidant activity of some Acacia species. Saudi J. Biol. Sci. 21 (5), 400-408. 
Afkir, S., Ngulefack, T.B., Aziz, M., Zoheir, J., Guisinaud, G., Bnouham, M., Mekhfi, H., Legsseyer, A., Lahlou, S., Ziyyat, A., 2008. Arbutus unedo prevents cardiovascular and morphological alterations in L-NAME-induced hypertensive rats, Part I: Cardiovascular and renal hemodynamic effects of Arbutus unedo in L-NAME-induced hypertensive rats. J. Ethnopharmacol. 116, 288-295.

Ait Youssef, M., 2006. Plantes médicinales de Kabylie.Edition Ibis Press, Paris,pp 37-38.

Akkol, E.K., Yeşilada, E., Güvenç, A., 2007. Evaluation of anti-inflammatory and antinociceptive activities of Erica species native to Turkey. J. Ethnopharmacol.116 (2), 251-257.

Ammar, H., Lopez, S.,Gonzalez, J.S., 2005. Assessment of the digestibility of some Mediterranean shrubs by in vitro techniques. Anim. Feed Sci. Technol. 119, 323-331.

Amezouar, F., Badri, W., Hsaine, M., Bourhim, N., Fougrach, H., 2013. Évaluation des activités antioxydante et anti-inflammatoire de Erica arborea L. du Maroc. Pathol. Biol. $61(6), 254-258$

Andrade, D., Gil, C., Breitenfeld, L., Domingues, F., Duarte, A.P., 2009. Bioactive extracts from Citrus ladanifer and Arbutus unedo L.Ind. Crops Prod. 30, 165-167.

Audibert, L., Fauchon, M., Blanc, N., Hauchard, D., Ar Gall, E., 2010. Phenolic compounds in the brown seaweed Ascophyllum nodosum: pool composition and radical-scavenging activities. Phytochem. Anal. 21 (5),399-405.

Ay, M., Bahadori, F., Öztürk, M., Kolak, U., Topçu, G., 2007. Antioxidant activity of Erica arborea. Fitoterapia.78, 571-573.

Ayaz, F.A., Kucukislamoglu, M., Reunanen, M., 2000. Sugar, non-volatile and phenolic acids composition of strawberry tree (Arbutus unedo L. Var. ellipsoidea) fruits. J. Food Compost. Anal. 13, 171-177. 
Barros, L., Carvalho, A.M., Sá Morais, J., Ferreira, I.C.F.R., 2010. Strawberry-tree, blackthorn and rose fruits: Detailed characterisation in nutrients and phytochemicals with antioxidant properties. Food Chem.120, 247-254.

Bezanger-Beauquesne, L., Pinkas, M., Torck, M., Trotin, F., 1990. Plantes médicinales des régions tempérées, second ed. Maloine, Paris,pp. 219.

Blanc, N., Hauchard, D., Audibert , L., Ar Gall, E., 2011. A Radical-scavenging capacity of phenol fractions in the brown seaweed Ascophyllum nodosum: an electrochemical approach. Talanta.84, 513-518.

Blois, M.S., 1958. Antioxidant determinations by the use of a stable free radical. Nature. 26, $1199-1200$

Bougatef, A., Hajji, M., Balti, R., Lassoued, I., Triki-Ellouz, Y., Nasri, M., 2009.Antioxidant and free radical-scavenging activities of smooth hound (Mustelus mustelus) muscle protein hydrolysates obtained by gastrointestinal proteases. Food Chem. 114, 1198-1205.

Bovy, A., Schijlen, E., Hall, R.D., 2007. Metabolomic engineering of flavonoids in tomato (Solanum lycopersicum): the potential for metabolomics. Metabolomics. 3 (3), 399-412.

Bramorski, A., da Rosa Cherem, A., Mezadri, T., Soares Melo, S., Carlos Deschamps, F., Valdemiro Gonzaga, L., Ivan Rockenbach, I., Fett, R., 2011. Chemical composition and antioxidant activity of Gaylussacia brasiliensis (camarinha) grown in Brazil. Food Res. Int. 44, 2134-2138.

Brantner, A., Grein, E., 1994. Antibacterial activity of plant extracts used externally in traditional medicine. J. Ethnopharmacol.44, 35-40.

Bruneton, J., 1987. Eléments de Phytochimie et de Pharmacognosie. Edition Lavoisier, Paris, pp. 136. 
Bruneton, J., 2001. Plantes toxiques : végétaux dangereux pour l'homme et les animaux, second ed. Lavoisier, Paris, pp. 241-242.

Chérigo, L., Pereda-Miranda, R., Gibbons, S., 2009. Bacterial resistance modifying tetrasaccharide agents from Ipomoea murucoides. Phytochemistry. 70, 222-227.

Dapremont-Avignon, C., Calas, P., Commeyras, A., Amatore, C., 1991. Synthesis of perfluoroalkyl carboxylic acids by reaction of perfluoroalkyl iodides with electrogenerated superoxide ion. J. Fluor. Chem.51, 357-379.

El Haouari, M., Lopez, J.J., Makhfi, H., Rosado, J.A., Salido, G.M., 2007. Antiaggregant effects of Arbutus unedo L. extracts in human platelets.J. Ethnopharmacol. 113 (2), $325-331$.

Fiorentino, A., Castaldi, S., Abrosca, B., Natale, A., Carfora, A., Messere, A., Monaco, P.,2007. Polyphenols from the hydro alcoholic extract of Arbutus unedo living in monospecific Mediterranean woodland. Biochem. Syst. Ecol. 35 (11), 809-811.

Fortalezas, S., Tavares, L., Pimpão, R., Tyagi, M., Pontes, V., Alves, P., McDougall, G., Stewart, D., Ferreira, R.B., Santos, C.N., 2010. Antioxidant properties and neuroprotective capacity of strawberry tree fruit (Arbutus unedo). Nutrients. 2, 214-229.

Garnier, G., Bezanger-Beauquesne, L., Derbreaux, G., 1961. Ressources médicinales de la flore Française, Tome II. Edition VIGOT, Paris, pp. 962-964.

Harnafi, H., Bouanani, N.H., Aziz, M., Caid, H.S., Ghalim, N., Amrani S., 2007. The hypolpidaemic activity of aqueous Erica multiflora $L$. flowers extract in triton WR-1339 induced hyperlipidaemic rats: A comparison with fenofibrate. J. Ethnopharmacol. 190 (1), 156-160.

Hatano, T., Kusuda, M., Inada, K., Ogawa, T., Shiota, S., Tsuchiya, T., Yoshida, T., 2005. Effects of tannins and related polyphenols on methicillin-resistant Staphylococcus aureus. Phytochemistry.66, 2047-2055. 
Havsteen, B.H., 2002. The biochemistry and medical significance of the flavonoids. Pharmacol. Ther. 96, 67-202.

Hernández, I., Alegre, L., Van Breusegem, F., Munné-Bosch, S., 2009. How relevant are flavonoids as antioxidants in plants? Trends Plant Sci. 14 (3), 125-132.

Huang, D., Ou, B., Prior, R.L., 2005. The chemistry behind antioxidant capacity assays. J. Agric. Food Chem. 53 (6), 1841-1856.

Jarrar, N., Abu-Hijleh, A., Adwan, K., 2010. Antibacterial activity of Rosmarinus officinalis L. alone and in combination with cefuroxime against methicillin-resistant Staphylococcus aureus. Asian Pac. J. Trop. Med. 121-123.

Kivcak, B., Mert, T., 2001. Quantitative determination of $\alpha$-tocopherol in Arbutus unedo by TLC-densitometry and colorimetry. Fitoterapia. 72, 656-661.

Lamaison, J.L.C., Carnet, A., 1990. Teneur en principaux flavonoïdes des fleurs de Cratageus monogyna Jacq et de Cratageus laevigata (Poiret D. C) en fonction de la végétation. Pharm. Acta Helv. 65, 315-320.

La Mantia,T., Giaimi, G., La melaveca, D.S., Pasta, S., 2007. The role of traditional Erica arborea L. Management practices in maintaining north eastern Sicily's cultural landscape. For. Ecol. Manage. 249, 63-70.

Le Bourvellec, C., Hauchard, D., Darchen, A., Burgot, J.L., Abasq, M.L., 2008. Validation of a new method using the reactivity of electrogenerated superoxide radical in the antioxidant capacity determination of flavonoids. Talanta.75 (4), 1098-1103.

Lhuillier, A., 2007. Contribution à l'étude phytochimique de quatre plantes Malgaches : Agauria sallicifolia Hook. F. Ex Olivier, Agauria polyphylla Baker (Ericaceae), Tambourissa trichophylla Baker (Mininiaceae) et Embelia concinnaBaker 
(Myrsinaceae). Thèse de doctorat de l'institut National Polytechnique de Toulouse, pp. 200.

Mackay, M.I., Milne, K., Gould, I.M., 2000. Comparison of methods for assessing synergic antibiotic interactions. Int. J. Antimicrob. Agents.15, 125-129.

Maleš, Ž., Plazibat, M., Vundac, V.B., Žuntar, I., 2006. Qualitative and quantitative analysis of flavonoids of the Strawberry tree-Arbutus unedo L. (Ericaceae). Acta Pharm.56, 245-250.

Mandal, S., DebMandal, M., Pal, N.K., Saha, K., 2010. Antibacterial activity of honey against clinical isolates of Escherichia coli, Pseudomonas aeruginosa and Salmonella enterica serovar Typhi. Asian Pac. J. Trop. Med. 3 (12), 961-964.

Mariotto, S., Esposito, E., Di Paola, R., Ciampaa, A., Mazzonc, E., de Prati, A.C., Darra, E., Vincenzi, S., Cucinotta, G., Caminiti, R., Suzuki, H., Cuzzocrea, S., 2008. Protective effect of Arbutus unedo aqueous extract in carrageenan-induced lung inflammation in mice. Pharmacol. Res. 57, 110-124.

Márquez-García, B., Fernández, M.A., Córdoba, F., 2009. Phenolics composition in Erica sp. differentially exposed to metal pollution in the Iberian Southwestern pyritic belt. Bioresour. Technol. 100, 446-451.

Mendes, L., Freitas, V., Baptista, P., Carvalho, M., 2011. Comparative antihemolytic and radical scavenging activities of strawberry tree (Arbutus unedo L.) leaf and fruit. Food Chem. Toxicol. 49, 2285-2291.

Meyer, S., Reeb, C., Bosdeveix, R., 2004. Botanique. Biologie et physiologie végétale. Edition Maloine, Paris, pp. 231.

Murray, P.R., Rosenthal, K.S., Pfaller, M.A., 2009. Medical Microbiology, sixth ed.Mosby Elsevier,Philadelphia, pp. 960. 
Newman, J., Cragg, G.M., 2012. Natural products as sources of new drugs over the 30 Years from 1981 to 2010. J. Nat. Prod.75 (3), 311-335.

Okusa, P.N., Penge, O., Devleeschouwer, M., Duez, P., 2007. Direct and indirect antimicrobial effects and antioxidant activity of Cordia gilletii De Wild (Boraginaceae). J. Ethnopharmacol.112, 476-481.

Oldham, K.B., Spanier, J., 1973. The fractional calculus. Academic Press, N. Y.

Oliveira, I., Coelho, V., Baltasar, R., Pereira, J.A., Baptista, P., 2009. Scavenging capacity of strawberry tree (Arbutus unedo L.) leaves on free-radicals. Food Chem. Toxicol. 47, $1507-1511$.

Ozcan, M.O., Haciseferogullan, H., 2007. The strawberry (Arbutus unedo L.) fruits: chemical composition, physical properties and mineral contents.J. Food Eng. 78 (3), 1022-1028.

Öztürk, M., Aydoğmuş-Öztürk, F., Duru, M.E., Topçu, G., 2007. Antioxidant activity of stem and root extracts of Rhubarb (Rheum ribes): An edible medicinal plant. Food Chem. $103,623-630$.

Pabuçcuoglu, A., Kıvcak, B., Bas, M., Mert, T., 2003. Antioxidant activity of Arbutus unedo leaves. Fitoterapia.74, 597-599.

Pallauf, K., Rivas-Gonzalo, J.C., Del Castillo, M.D., Cano, M.P., Pascual-Teresa, S., 2008. Characterization of the antioxidant composition of strawberry tree (Arbutus unedo L.) fruits. J. Food Compost. Anal. 21(4), 273-281.

Parejo, I., Viladomat, F., Bastida, J., Rosas-Romero, A., Saavedra, G., Murcia, M.A., Jimenez, A.M., Codina, C., 2003. Investigation of Bolivian plant extracts for their radical scavenging activity and antioxidant activity. Life Sci. 73, 1667-1681.

Re, R., Pellegrini, N., Proteggente, A., Pannala, A., Yang, M., Rice-Evans, C., 1999. Antioxidant activity applying an improved ABTS radical cation decolorization assay. Free Radic. Biol. Med. 26, 1231-1237. 
Rios, J.L., Recio, M.C., Villar, A., 1987. Antimicrobial activity of selected plants employed in the Spanish Mediterranean area. J. Ethnopharmacol. 21, 139-152.

Ruiz-Rodríguez, B.M., Morales, P., Fernández-Ruiz, V., Sánchez-Mata, M.C., Cámara, M., Díez-Marqués, C., Pardo-de-Santayana, M., Molina, M., Tardío, J., 2011. Valorization of wild strawberry-tree fruits (Arbutus unedo L.) through nutritional assessment and natural production data. Food Res. Int.44 (5), 1244-1253.

Sadki, C., Hacht, B., Amrani, S., Atmani, F., 2010. Acute diuretic activity of aqueous Erica multiflora flowers and cynodon dactylon rhizomes extracts in rats. J. Ethnopharmacol. $128(2), 352-356$.

Samarth, R.M., Panwar, M., Kumar, M., Soni, A., Kumar, M., Kumar, A., 2008. Evaluation of antioxidant and radical-scavenging activities of certain radioprotective plant extracts. Food Chem. 106, 868-873.

Serçe, S., O“zgen, M., Torun, A.A., Ercisli, S., 2010. Chemical composition, antioxidant activities and total phenolic content of Arbutus andrachne L. (Fam. Ericaceae) (the Greek strawberry tree) fruits from Turkey. J. Food Compost. Anal. 23, 619-623.

Singleton, V.L., Rossi, J.A., 1965. Colorimetry of total phenolics with phosphomolybdicphosphotungstic acid reagents. Am. J. Enol. Vitic. 16(3), 144-158.

Soares, A.A., Marques de Souza, C.G., Daniel, F.M., Ferrari, G.P., Gomes da Costa, S.M., Peralta, R.M., 2009. Antioxidant activity and total phenolic content of Agaricus brasiliensis (Agaricus blazei Murril) in two stages of maturity. Food Chem. 112, 775781.

Takrouni, M.M., Boussaid, M., 2010. Genetic diversity and population's structure in Tunisian strawberry tree (Arbutus unedo L.). Sci.Hortic. 126, 330-337.

Valnet, J., 1992. Phytothérapie : traitement des maladies par les plantes. Edition Maloine, Paris, pp. 206. 
Vasco, C., Ruales, J., Kamal-Eldin, A., 2008. Total phenolic compounds and antioxidant capacities of major fruits from Ecuador. Food Chem. 111, 816-823.

Vilà, M., Terradas, J., 1998. Neighbour effects on Erica multiflora (Ericaceae) reproductive performance after clipping. Acta oecol. 19 (2), 139-145.

Villareal, M.O., Han, J., Matsuyama, K., Sekii, Y., Smaoui, A., Shigemori, H., Isoda, H., 2013. Lupenone from Erica multiflora leaf extract stimulates melanogenesis in B16 murine melanoma cells through the inhibition of ERK1/2 activation. Planta Med. 79, 236-243.

Wagner, H., Bladt, S., 1996. Plant Drug Analysis. A thin layer chromatography atlas,second ed. Springer-Verlag, Berlin Heidelberg.

Wagner, H., Ulrich-Merzenich, G., 2009. Synergy research: Approaching a new generation of phytopharmaceuticals. Phytomedicine. 16 (2-3), 97-110.

Williams, R.J., Spencer, J.P.E., Rice-Evans, C., 2004. Flavonoids: antioxidants or signaling molecules? Free Radic. Biol. Med. 36 (7), 838-849.

Xia, X., Cao, J., Zheng, Y., Wang, Q., Xiao, J., 2014. Flavonoid concentrations and bioactivity of flavonoid extracts from 19 species of ferns from China. Ind.Crops Prod. $58,91-98$. 


\section{Table 1}

Content of total phenolic compounds, flavonoids, and antioxidant activity of Ericaceae species.

\begin{tabular}{|c|c|c|c|c|c|}
\hline \multirow[t]{2}{*}{ Sample } & \multirow{2}{*}{$\begin{array}{l}\text { Total phenolic } \\
\text { compounds } \\
(\text { mg GAE/g } \\
\text { DW })^{(\mathrm{a}, \mathrm{b})}\end{array}$} & \multirow{2}{*}{$\begin{array}{c}\text { Total } \\
\text { flavonoids } \\
(\mathrm{mg} \mathrm{QE} / \mathrm{g} \\
\mathrm{DW})^{(\mathrm{b}, \mathrm{c})}\end{array}$} & \multicolumn{3}{|c|}{ Antioxidant activity } \\
\hline & & & $\begin{array}{c}\text { Quenching } \\
\text { of DPPH } \\
\text { IC }_{50} \\
(\mathrm{mg} / \mathrm{L})\end{array}$ & $\begin{array}{c}\text { Quenching } \\
\text { of } \mathrm{ABTS}^{\circ+} \\
\mathrm{IC}_{50} \\
(\mathrm{mg} / \mathrm{L})\end{array}$ & $\begin{array}{c}\text { Quenching of } \\
\mathrm{O}_{2}{ }^{-} \mathrm{AI}_{50} \\
\mathrm{AI}_{30} \\
(\mathrm{mg} / \mathrm{L})\end{array}$ \\
\hline $\begin{array}{l}\text { E.arborea } \\
\text { flowering } \\
\text { aerial parts }\end{array}$ & $70.8 \pm 2.5$ & $9.5 \pm 0.1$ & $5.7 \pm 0.08$ & $6.8 \pm 0.1$ & $\begin{array}{l}213 \pm 7 \\
115 \pm 3\end{array}$ \\
\hline $\begin{array}{l}\text { E.multiflora } \\
\text { flowering } \\
\text { aerial parts }\end{array}$ & $68.2 \pm 3.2$ & $6.5 \pm 0.3$ & $10.2 \pm 0.3$ & $9.0 \pm 0.1$ & $\begin{array}{l}261 \pm 4 \\
149 \pm 6\end{array}$ \\
\hline $\begin{array}{l}\text { A.unedo } \\
\text { leaves }\end{array}$ & $179.6 \pm 6.7$ & $21.4 \pm 0.01$ & $3.8 \pm 0.2$ & $4.2 \pm 0.4$ & $\begin{array}{c}185 \pm 5 \\
96 \pm 4\end{array}$ \\
\hline
\end{tabular}

\footnotetext{
(a) $\mathrm{GAE}=$ Gallic acid equivalents.

(b) DW = Dry weight

(c) $\mathrm{QE}=$ Quercetin equivalents
} 
Table 2

The MICs (mg/L) of the different plant extract and control antibiotics.

\begin{tabular}{lcccc}
\hline $\begin{array}{l}\text { Plant extract and } \\
\text { antibiotics }\end{array}$ & $\begin{array}{c}\text { S. aureus } \\
\text { ATCC 6538 }\end{array}$ & $\begin{array}{c}\text { S. aureus } \\
\text { C 100459 (MRSA) }\end{array}$ & $\begin{array}{c}\text { P. aeruginosa } \\
\text { ATCC 9027 }\end{array}$ & $\begin{array}{c}\text { E.coli } \\
\text { ATCC 25922 }\end{array}$ \\
\hline $\begin{array}{l}\text { E. arborea flowering } \\
\text { aerial parts }\end{array}$ & 500 & 250 & 2000 & $>2000$ \\
$\begin{array}{l}\text { E. } \text { multiflora } \\
\text { flowering aerial parts }\end{array}$ & 250 & 250 & 2000 & $>2000$ \\
$\begin{array}{l}\text { A. unedo leaves } \\
\text { Cefotaxim }\end{array}$ & 125 & 125 & 1000 & 1000 \\
\hline Penicillin & 1 & 4 & 16 & $\mathrm{nd}^{(\mathrm{a})}$ \\
\hline
\end{tabular}

(a) nd: not determined. 
Table 3

The MBCs (mg/L) of the different plant extracts.

\begin{tabular}{lcccc}
\hline Plant extract & $\begin{array}{c}\text { S. aureus } \\
\text { ATCC 6538 }\end{array}$ & $\begin{array}{c}\text { S. aureus } \\
\text { C 100459 (MRSA) }\end{array}$ & $\begin{array}{c}\text { P. aeruginosa } \\
\text { ATCC 9027 }\end{array}$ & $\begin{array}{c}\text { E.coli } \\
\text { ATCC 25922 }\end{array}$ \\
\hline $\begin{array}{l}\text { E.arborea flowering } \\
\text { aerial parts }\end{array}$ & $\begin{array}{c}500 \\
\text { (bactericidal) }\end{array}$ & $\begin{array}{c}1000 \\
\text { (bactericidal) }\end{array}$ & 2000 & nd \\
$\begin{array}{l}\text { E.multiflora flowering } \\
\text { aerial parts }\end{array}$ & $\begin{array}{c}1000 \\
\text { (bactericidal) }\end{array}$ & $\begin{array}{c}500 \\
\text { (bactericidal) }\end{array}$ & 2000 & $>2000$ \\
$\begin{array}{l}\text { A.unedo } \\
\text { leaves }\end{array}$ & 250 & $\begin{array}{c}500 \\
\text { (bactericidal ) }\end{array}$ & 2000 & $>2000$ \\
\hline
\end{tabular}




\section{Table 4}

Interaction between plant extracts and antibiotics.

\begin{tabular}{lllll}
\hline \multirow{2}{*}{$\begin{array}{l}\text { Antibiotic-Plant } \\
\text { extract }\end{array}$} & \multicolumn{2}{c}{ S. aureus C 100459 (MRSA) } & \multicolumn{2}{l}{ P. aeruginosa ATCC 9027 } \\
\cline { 2 - 5 } & FIC Index & Interaction & FIC Index & Interaction \\
\hline Cefo/E.arborea $^{\text {(a) }}$ & 1 & Additive & 1.125 & Indifference \\
Cefo/E.multiflora & 1 & Additive & 1.5 & Indiferrence \\
Cefo/A.unedo & 1.5 & Indifference & 1.25 & Indifference \\
\hline Strep/E.arborea & 1 & Additive & nd $^{(\mathrm{b})}$ & $\mathrm{nd}$ \\
Strep/E.multiflora & 1 & Additive & nd & nd \\
Strep/A.unedo & 1.5 & Indifference & nd & nd \\
\hline
\end{tabular}

(a) Cefo: cefotaxim; Strep: streptomycin. 
Table 5

Major polyphenols identified in the three Algerian Ericaceae.

\begin{tabular}{|c|c|c|c|}
\hline Compounds & $\operatorname{Tr}(\min )$ & $\mathrm{m} / \mathrm{Z}$ & Species \\
\hline Epicatechin & 4.28 & 289.10 & A. unedo \\
\hline Caffeic acid & 4.95 & 179.00 & E. arborea, E. multiflora, $A$. unedo \\
\hline p-Coumaric acid & 8.33 & 163.18 & E. arborea, E. multiflora, A. unedo \\
\hline Naringin & 11.47 & 507.50 & E. multiflora \\
\hline Quercetin & 21.74 & 301,10 & E. arborea, E. multiflora, A. unedo \\
\hline$t$-Cinnamic acid & 15.70 & 147.00 & E. arborea, A.unedo \\
\hline Kaempferol $^{(\mathrm{a})}$ & 28.42 & 285.00 & E. multiflora, A. unedo \\
\hline
\end{tabular}

(a) This peak was identified as kaempferol after acidic hydrolysis of the extract; the structure of the glycoside has not been determined. 


\section{Figure captions}

Fig.1. Cyclic Voltammograms of $\mathrm{O}_{2}$ in absence and presence of increasing concentrations of A.unedophenolic extract at a steady glassy carbon disk electrode in $\mathrm{DMF} / 0.1 \mathrm{M} \mathrm{Bu} \mathrm{BPF}_{6}$. Scan rate $0.1 \mathrm{Vs}^{-1}$. (A) Time semi-derivative convoluted curves; (B) CV curves.

Fig. 2. TLC profiles of the three Algerian Ericaceae (1: chlorogenic acid, 2: caffeic acid, 3: quercetin, 4: E. arborea, 5: hydrolysed E. arborea, 6: gallic acid, 7: kaempferol, 8: arbutin, 9: E.multiflora, 10: hydrolysed E. multiflora, 11: ellagic acid, 12: 7-glucosid apigenin, 13: A. unedo, 14: hydrolysed A. unedo, 15: rutin, 16: epicatechin). The analysis was performed on Silicagel 60 F254 plates. The solvent system used was ethyl acetate, formic acid and water (90:6:6, v/v/v); plates were sprayed with a solution of aminoethanol diphenylborate (1\% $\mathrm{MeOH})$ then a solution of macrogol $400(5 \% \mathrm{MeOH})$ and visualized under UV $366 \mathrm{~nm}$. The extracts were analyzed before and after acid hydrolysis (with $\mathrm{HCl} 1.2 \mathrm{M}, 100^{\circ} \mathrm{C}, 1 \mathrm{~h}$ ).

Fig.3. Total ion chromatogram of the E .multiflora methanolic extract (6: naringin, 10: quercetin and 14: kaempferol). 


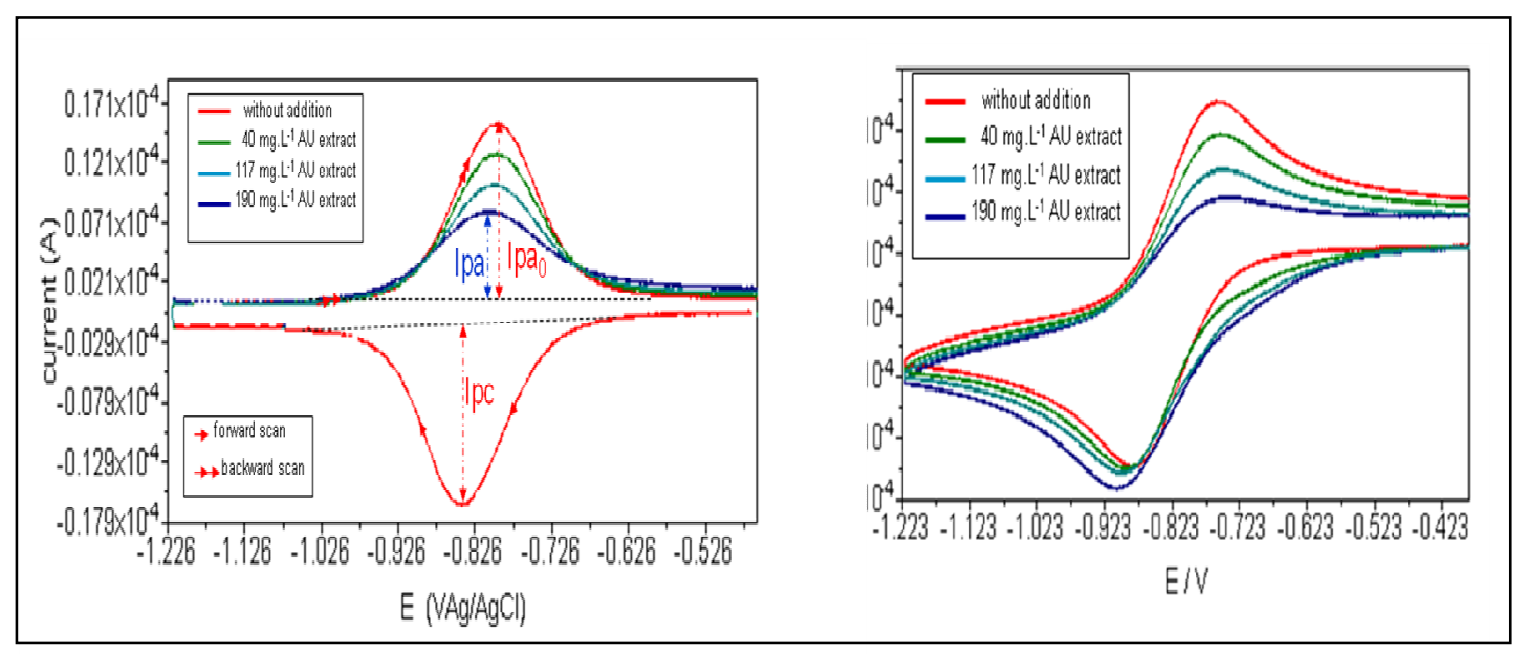

Fig.1. 


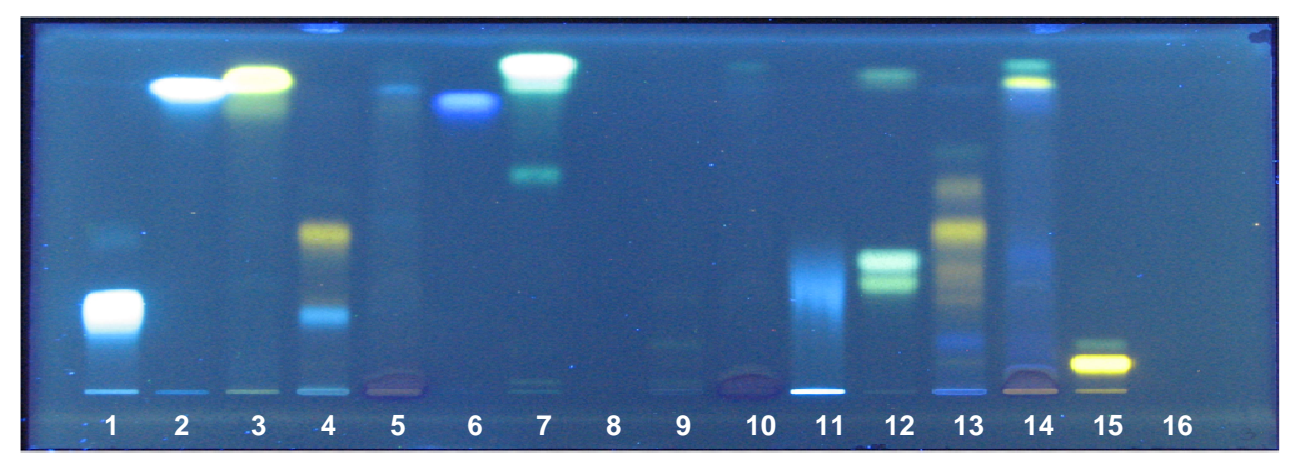

Fig. 2. 


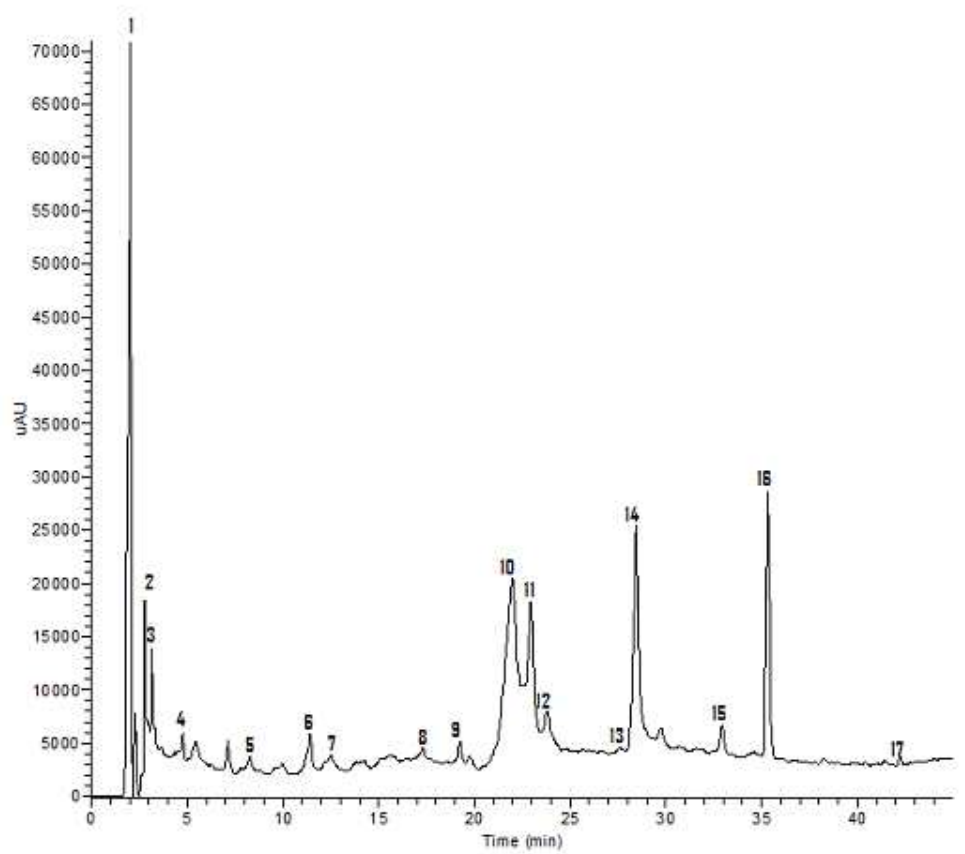

Fig.3. 